\title{
Lansoprazole, a Proton Pump Inhibitor, Suppresses Production of Tumor Necrosis Factor- $\alpha$ and Interleukin-1 $\beta$ Induced by Lipopolysaccharide and Helicobacter Pylori Bacterial Components in Human Monocytic Cells via Inhibition of Activation of Nuclear Factor-kB and Extracellular Signal-Regulated Kinase
}

\author{
Tetsuya Tanigawa ${ }^{1, *}$, Toshio Watanabe ${ }^{1}$, Kazuhide Higuchi $^{2}$, Hirohisa Machida ${ }^{1}$, \\ Hirotoshi Okazaki', Hirokazu Yamagami', Kenji Watanabe' ${ }^{1}$, Kazunari Tominaga', \\ Yasuhiro Fujiwara ${ }^{1}$, Nobuhide Oshitani ${ }^{1}$, and Tetsuo Arakawa ${ }^{1}$ \\ ${ }^{1}$ Department of Gastroenterology, Osaka City University Graduate School of Medicine, Osaka 545-8585, Japan \\ ${ }^{2}$ Second Department of Internal Medicine, Osaka Medical Collage, Takatsuki 569-8686, Japan
}

Received 28 December, 2008; Accepted 13 January, 2009

\begin{abstract}
Summary Pathogenic bacterial components play critical roles in initiation of gastrointestinal inflammation via activation of intracellular signaling pathways which induce proinflammatory cytokines such as tumor necrosis factor (TNF)- $\alpha$ and interleukin (IL)-1ß. Lansoprazole (LANSO), a proton pump inhibitor, has been widely used for the treatment of peptic ulcers and reflux esophagitis due to its potent acid-suppressive effect. It has also been reported to have anti-inflammatory effects. In this study we investigated the effects of LANSO on the production of TNF- $\alpha$ and IL-1 $\beta$ induced by lipopolysaccharide (LPS) and Helicobacter pylori water-soluble extract (HpWE) in the human monocytic cell line (THP-1). LANSO $(100 \mu \mathrm{M})$ significantly reduced mRNA expression and production of TNF- $\alpha$ and IL-1 $\beta$ by THP-1 cells stimulated by LPS and HpWE. LANSO inhibited phosphorylation and degradation of inhibitory factor $\kappa B-\alpha(I \kappa B-\alpha)$ and phosphorylation of extracellular signal-regulated kinase (ERK) induced by LPS and HpWE in THP-1 cells. These findings suggest that LANSO exerts antiinflammatory effects by suppressing induction of TNF- $\alpha$ and IL-1 $\beta$ via inhibition of nuclear factor (NF)-KB and ERK activation.
\end{abstract}

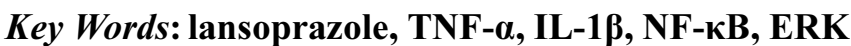

Introduction

Pathogenic bacteria play crucial roles in the pathophysiology of gastrointestinal inflammation. For instance, Helicobacter pylori (H. pylori) infection is strongly associated with chronic active gastritis [1-3]. Enterobacteria contribute to the pathogenesis of inflammatory bowel diseases [4].

\footnotetext{
*To whom correspondence should be addressed.

Tel: +81-6-6645-3811 Fax: +81-6-6645-3813

E-mail: ttanigawa@med.osaka-cu.ac.jp
}

Moreover, recent studies suggest that the presence of enterobacteria is essential for the development of nonsteroidal anti-inflammatory drugs (NSAIDs)-induced small intestinal injury [5-7].

In the process of gastrointestinal inflammation triggered by bacteria, binding of bacterial components to receptors on the surface of effector cells including monocytes/macrophages is a critical initial step [8]. Proinflammatory responses initiated by bacteria are elicited by the interaction of bacterial components with Toll-like receptors (TLRs) expressed on monocytes/macrophages [9]. For example, lipopolysaccharide (LPS), derived from outer membrane of 
Gram-negative bacteria, binds to TLR4, and signaling by it leads to activation of nuclear factor (NF)- $\kappa \mathrm{B}$ and mitogenactivated protein kinase (MAPK) signaling pathways, which subsequently induce a variety of genes involved in inflammatory responses such as tumor necrosis factor (TNF)- $\alpha$ and interleukin(IL)-1 $\beta$. It also appears that $H$. pylori stimulates TLR, although the subtype responsible for this remains controversial $[10,11]$. These intracellular signaling pathways from receptors to the nucleus could be a therapeutic target for prevention and regulation of deleterious inflammatory responses which may lead to progression of disease or impairment of gastrointestinal physiological function.

Lansoprazole (LANSO), a proton pump inhibitor, has been widely used for the treatment of peptic ulcers and reflux esophagitis due to its potent acid-suppressive effects mediated via inhibition of p-type $\mathrm{H}^{+} \mathrm{K}^{+}$-adenosine triphosphatase. LANSO has also been reported to have antiinflammatory effects [12-22]. However, the precise mechanism of its anti-inflammatory effects remains unclear.

In this study, we investigated the effects of LANSO on LPS- or $H$. pylori-induced production of TNF- $\alpha$ and IL- $1 \beta$ by the human monocytic cell line THP-1 and attempted to elucidate the underlying anti-inflammatory mechanism of LANSO.

\section{Materials and Methods}

\section{Materials}

LPS (Escherichia coli O55:B5), pyrrolidinedithiocarbamate (PDTC), an inhibitor of NF- $\mathrm{B}$ activation, and PD98059, a MAPK/extracellular signal-regulated kinase (ERK) kinase (MEK) inhibitor, were purchased from Sigma (St. Louis, MO). Antibody to inhibitory factor $\kappa \mathrm{B}-\alpha(\mathrm{I} \kappa \mathrm{B}-\alpha)$ and phosphorylated I $\mathrm{K}$ B- $\alpha$ was purchased from Cell Signaling Technology (Danvers, MA), and antibody for ERK2 and phosphorylated ERK2 was purchased from Santa Cruz Biotechnology (Santa Cruz, CA). LANSO was a gift from Takeda Pharmaceuticals (Osaka, Japan).

\section{Preparation of $H$. pylori water-soluble extract (HpWE)}

H. pylori (ATCC 43505 strain, cag $A^{+}$and vac $A^{+}$) was grown to a concentration of $2.0 \times 10^{8}$ colony-forming units (CFUs)/ml in Brucella broth (BBL, Cockeysville, MD) containing $10 \%$ sterile heat-inactivated horse serum. The flasks were incubated at $37^{\circ} \mathrm{C}$ for $24 \mathrm{~h}$ under microaerophilic conditions with agitation on a rotary shaker at $160 \mathrm{rpm}$. After centrifugation of $H$. pylori-containing broth culture at $8300 \mathrm{rpm}$ for $20 \mathrm{~min}$ at $4^{\circ} \mathrm{C}$, supernatant was discarded and cold PBS was added to the tube. After washing the bacterial pellet with gentle inversion, the bacterial suspension was centrifuged at $8300 \mathrm{rpm}$ for $10 \mathrm{~min}$ at $4^{\circ} \mathrm{C}$. This washing procedure was repeated three times, and finally the cell suspension was sonicated for $30 \mathrm{~s}$. The suspension was then centrifuged at $14000 \mathrm{rpm}$ for $30 \mathrm{~min}$ at $4^{\circ} \mathrm{C}$. The supernatant was then passed through a $0.22 \mu \mathrm{m}$ filter unit (Nihon Millipore KK, Tokyo, Japan). This procedure removes much of the high-molecular-weight complex material, which mainly consists of membrane vesicles and intact flagella. Filtered supernatant was stored at $-80^{\circ} \mathrm{C}$ until experimentation.

\section{Cell culture}

THP-1 was purchased from American Type Culture Collection (Manassas, VA). Cells were routinely maintained in RPMI 1640 medium supplemented with $10 \%$ fetal bovine serum. LPS (10 ng/mL) or HpWE $(5 \mu \mathrm{g} / \mathrm{ml})$ was added and incubated for up to $3 \mathrm{~h}$ with or without preincubation with LANSO $(100 \mu \mathrm{M})$ dissolved in dimethyl sulfoxide (DMSO) for $3 \mathrm{~h}$. In another series of experiments, cells were pretreated with $100 \mu \mathrm{M}$ of PDTC or $10 \mu \mathrm{M}$ or PD98059 for $30 \mathrm{~min}$ and LPS or HpWE was added and incubated for $3 \mathrm{~h}$.

\section{Enzyme-linked Immunosorbent Assay (ELISA)}

Cell culture supernatant was collected and production of TNF- $\alpha$ and IL-1 $\beta$ was determined using a commercial ELISA kit (R\&D Systems, Minneapolis, MN) according to the manufacturer's instructions.

Determination of expression of $m R N A$ for $T N F-\alpha$ and $I L-1 \beta$ by real-time quantitative $R T-P C R$

Total RNA was isolated using an ISOGEN kit (Nippon Gene, Tokyo, Japan) according to the manufacturer's protocol. PCR primers and TaqMan probes for TNF- $\alpha$ and IL-1 $\beta$ were designed using Primer Express, a software program (PE Applied Biosystems, Foster City, CA). TaqMan probes were labeled with a reporter fluorescent dye (6-carboxyfluorescein) at the 5' end and a fluorescent dye quencher (6-carboxytetramethylrhodamine) at the 3' end. For TNF- $\alpha$, the sense primer was 5-TCATGCACCACCATCAAGGA-3, the antisense primer was 5-GAGGCAACCTGACCACTCTCC-3, and the TaqMan probe was 5AATGGGCTTTCCGAATTCACTGGAGC-3. For IL-1 $\beta$, the sense primer was 5-ACAGGCTCCGAGATGAACAAC-3, the antisense primer was 5-CCATTGAGGTGGAGAGCTTTC-3, and the TaqMan probe was 5-AAAAAGCCTCGTGCTGTCGGACCCATAT-3. Real-time quantitative RT-PCR analyses were performed using an ABI PRISM 7700 Sequence Detection System instrument and software (PE Applied Biosystems). The reaction mixture was prepared according to the manufacturer's protocol using the Platinum qRT-PCR ThermoScript One-Step System (Invitrogen, Carlsbad, CA). Thermal cycling conditions comprised $50^{\circ} \mathrm{C}$ for $30 \mathrm{~min}$ and $95^{\circ} \mathrm{C}$ for $5 \mathrm{~min}$, followed by 45 cycles of amplification at $95^{\circ} \mathrm{C}$ for $15 \mathrm{~s}$ and $60^{\circ} \mathrm{C}$ for $1 \mathrm{~min}$. Total RNA was subjected to real-time quantitative 
RT-PCR for measurement of target genes and GAPDH as an internal standard using TaqMan GAPDH control reagents (PE Applied Biosystems). Expression of mRNA for TNF- $\alpha$ and IL- $1 \beta$ was standardized to GAPDH mRNA and mRNA levels were expressed as ratios to the mean value for vehicle (DMSO)-treated control cells.

\section{Western blot analysis}

Cells were homogenized and lysed on ice in a buffer containing 0.5\% NP-40, $40 \mathrm{mM}$ Tris $\mathrm{HCl}$ (pH 8.0), $120 \mathrm{mM}$ $\mathrm{NaCl}$ and a protease inhibitor cocktail (Complete Mini, Pierce, Rockford, IL). Protein in the lysate was measured with a modified bicinchoninic acid method (Pierce, Rockford, IL). Proteins were denatured with SDS sample buffer, subjected to SDS-polyacrylamide gel electrophoresis, and transferred to a PVDF membrane. Membranes were blocked in TBS buffer containing 5\% skim milk and were then incubated overnight with antibodies to IкB- $\alpha$, phosphorylated I $\mathrm{KB}-\alpha$, phosphorylated ERK, or ERK2. The bound antigen-antibody complexes were detected with anti-rabbit or mouse IgG-HRP, using enhanced chemiluminescence in accordance with the manufacturer's instructions (Amersham, Arlington Heights, IL).

\section{Statistical Analysis}

Values are the mean \pm SD. One-way analysis of variance was used to test for significance of differences among treatment group means, and results were examined by Fisher's protected least-significant-difference test. Differences with $p$ values less than 0.05 were considered significant.

\section{Results}

LANSO inhibits LPS-induced TNF- $\alpha$ and IL-1 $\beta$ gene expression and protein production

Although unstimulated THP-1 cells constitutively express mRNA for TNF- $\alpha$ and IL-1 $\beta$, production of TNF- $\alpha$ and IL-1 $\beta$ protein was not detected in culture supernatant in which THP-1 cells were grown for $6 \mathrm{~h}$ by ELISA because of the sensitivity of the experimental system used in the present study. LPS increased expression of mRNA for TNF- $\alpha$ by 176 -fold after one-hr and by 185 -fold after two-hr incubation with LPS. Similar to TNF- $\alpha$, LPS induced expression of mRNA for IL-1 $\beta$ by 319 -fold after one-hr and 802-fold after two-hr incubation with LPS. LPS induced protein production of TNF- $\alpha$ and IL- $1 \beta$ after $3 \mathrm{~h}$ of incubation with LPS. Pretreatment with $100 \mu \mathrm{M}$ of LANSO for $3 \mathrm{~h}$ decreased LPS-induced expression of mRNA for TNF- $\alpha$ by $57 \%$ and protein production of TNF- $\alpha$ protein by $51 \%$. LPS also inhibited expression of mRNA for IL- $1 \beta$ by $62 \%$ and protein production of IL- $1 \beta$ by $71 \%$ (Fig. 1 ).
LANSO inhibits HpWE-induced TNF- $\alpha$ and IL-1 $\beta$ gene expression and protein production

HpWE increased expression of mRNA for TNF- $\alpha$ by 48fold after two-hr incubation with HpWE. Similar to TNF- $\alpha$, HpWE induced expression of mRNA for IL- $1 \beta$ by 200 -fold after two-hr incubation with HpWE. HpWE induced protein production of TNF- $\alpha$ and IL-1 $\beta$ after $3 \mathrm{~h}$ of incubation with HpWE. Pretreatment with $100 \mu \mathrm{M}$ LANSO for $3 \mathrm{~h}$ decreased HpWE-induced expression of mRNA for TNF- $\alpha$ by $27 \%$ and protein production of TNF- $\alpha$ by $48 \%$. LPS also inhibited expression of mRNA for IL- $1 \beta$ by $50 \%$ and protein production of IL- $1 \beta$ by $93 \%$ (Fig. 2).

\section{Inhibition of NF- $\kappa B$ and ERK decreases LPS-induced production of TNF- $\alpha$ in THP-1 cells}

To confirm the relevance of NF- $\mathrm{KB}$ and ERK to production of TNF- $\alpha$ by THP-1 cells stimulated by LPS, we examined the effects of PDTC, an inhibitor of NF- $\mathrm{KB}$ activation, and PD 98059, a MEK inhibitor. Pretreatment with PDTC or PD98059 decreased the protein production of TNF- $\alpha$ by THP- 1 cells stimulated by LPS (Fig. 3 ) by $54 \%$ and $34 \%$, respectively. These findings indicate that activation of NF- $\mathrm{KB}$ and ERK is responsible for production of TNF- $\alpha$ by THP-1 cells stimulated by LPS (Fig. 3 ).

LANSO inhibits LPS-induced phosphorylation and degradation of I $\kappa$ - $\alpha$ and phosphorylation of ERK

Stimulation with LPS for one hr induced phosphorylation and degradation of IKB- $\alpha$ and phosphorylation of ERK. Pretreatment with LANSO for one hr inhibited LPS-induced phosphorylation and degradation of IKB- $\alpha$ and phosphorylation of ERK (Fig. 4).

LANSO inhibits HpWE-induced phosphorylation and degradation of I $\kappa B-\alpha$ and phosphorylation of ERK

Similar to LPS, stimulation with HpWE for one $\mathrm{hr}$ induced phosphorylation and degradation of IKB- $\alpha$ and phosphorylation of ERK. Pretreatment with LANSO for one hr inhibited HpWE-induced phosphorylation and degradation of IKB- $\alpha$ and phosphorylation of ERK (Fig. 5).

\section{Discussion}

In the present study, we demonstrated that LANSO inhibits LPS and HpWE-induced transcription and production of TNF- $\alpha$ and IL-1 $\beta$. We also showed that LANSO inhibited activation of NF- $\kappa$ B and ERK induced by LPS and HpWE, which could account for why LANSO exerts antiinflammatory effects.

Production of proinflammatory cytokines such as TNF- $\alpha$ and IL-1 $\beta$ by inflammatory cells is one of the pivotal processes in gastrointestinal inflammation. In response to interaction with pathogenic bacteria, inflammatory cells 

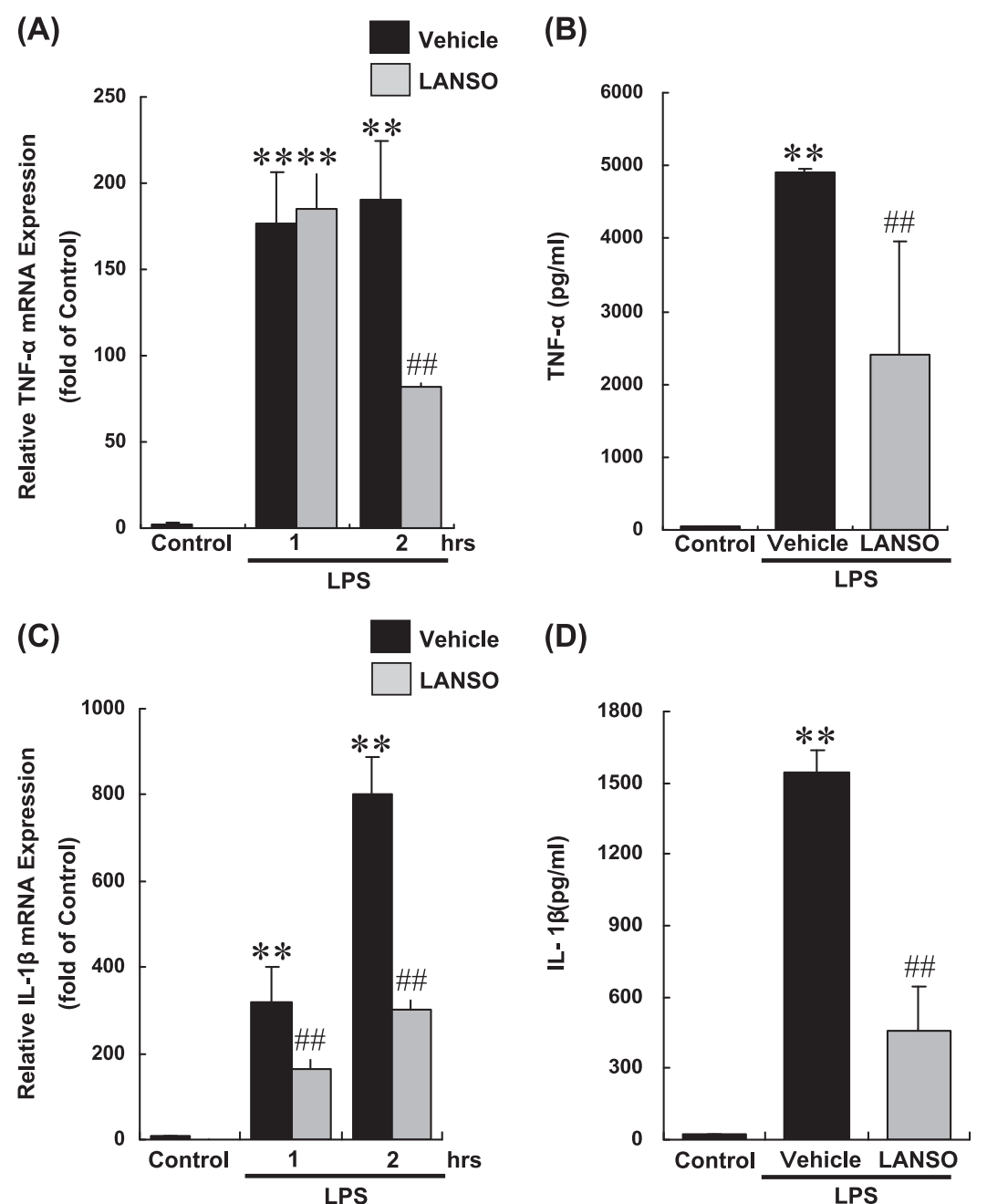

Fig. 1. Effects of LANSO on expression of TNF- $\alpha$ and IL-1 $\beta$ induced by LPS in human monocytes (THP-1). After pretreatment with $100 \mu \mathrm{M}$ of LANSO for $3 \mathrm{~h}$, THP-1 cells were stimulated with LPS (10 ng/ml) for up to $3 \mathrm{~h}$. (A) Expression of mRNA for TNF$\alpha$ and (B) concentration of TNF- $\alpha$ protein in cell culture supernatant were determined by real-time quantitative RT-PCR and ELISA, respectively. (C) Expression of mRNA for IL-1 $\beta$ and (D) concentration of IL-1 $\beta$ protein in cell culture supernatant were determined by real-time quantitative RT-PCR and ELISA, respectively. Each column represents the mean \pm SD of $n=3$ independent observations in three separate cell culture plates. ${ }^{* *} ; p<0.01$ compared with control. ${ }^{\# ;} ; p<0.01$ compared with LPS-stimulated vehicle-treated cells.

produce proinflammatory cytokines, which activate further inflammatory processes and promote inflammation. In the present study, we showed that LANSO inhibits production of TNF- $\alpha$ and IL-1 $\beta$ by the monocytic cell line THP-1 stimulated by LPS or HpWE. Moreover, Nakamura et al. reported that uptake of LANSO was observed in inflammatory cells including polymorphonuclear cells and macrophages in the colonic mucosa of rats with dextran sodium sulfate-induced colitis [23]. These findings suggest that LANSO may exert anti-inflammatory effects in gastrointestinal inflammation via suppression of production of proinflammatory cytokines from inflammatory cells stimulated by pathogenic bacteria.
Several reports have suggested mechanisms by which LANSO and other proton pump inhibitors exert antiinflammatory effects [12-22]. In the present study, we focused on the NF- $\mathrm{KB}$ and ERK signaling pathways, since they are important transcription factors of critical importance for induction of production of proinflammatory cytokines by monocytes stimulated by LPS [24-26] or HpWE [27]. Our study demonstrated that the suppression of TNF- $\alpha$ and IL- $1 \beta$ induced by LPS and HpWE was accompanied by inhibition of phosphorylation and degradation of IкB- $\alpha$ and phosphorylation of ERK. These findings suggest that the inhibitory effect of LANSO on expression of TNF- $\alpha$ and IL- $1 \beta$ by THP- 1 cells stimulated by LPS and HpWE was associated with inhibition of the NF-KB or ERK signaling 

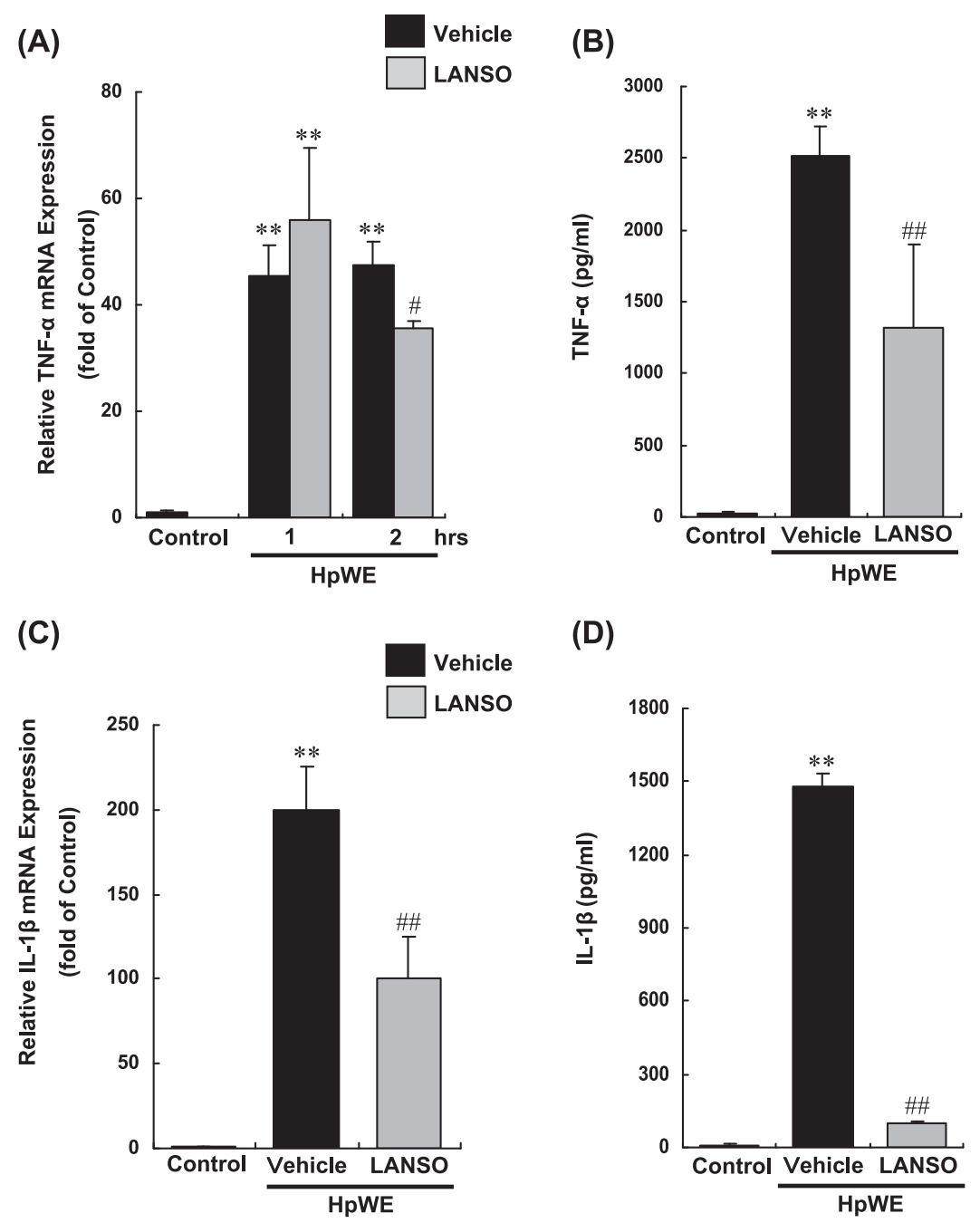

(D)

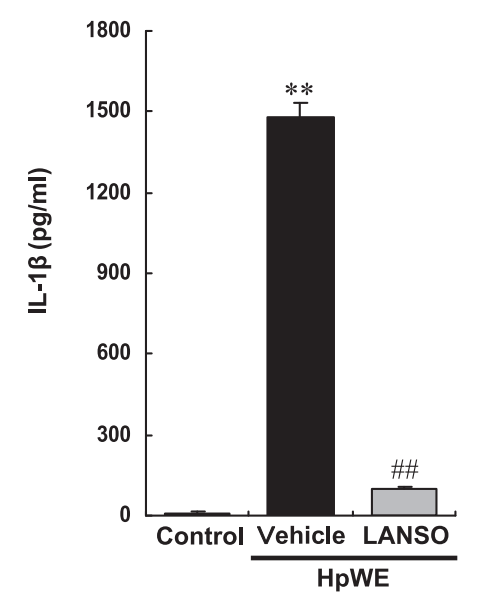

Fig. 2. Effects of LANSO on expression of TNF- $\alpha$ and IL-1 $\beta$ induced by HpWE in human monocytes (THP-1). After pretreatment with $100 \mu \mathrm{M}$ of LANSO for $3 \mathrm{~h}$, THP-1 cells were stimulated with $\mathrm{HpWE}(5 \mu \mathrm{g} / \mathrm{ml}$ ) for up to $3 \mathrm{~h}$. (A) Expression of mRNA for TNF- $\alpha$ and (B) concentration of TNF- $\alpha$ protein in cell culture supernatant were determined by real-time quantitative RT-PCR and ELISA, respectively. (C) Expression of mRNA for IL-1 $\beta$ and (D) concentration of IL-1 $\beta$ protein in cell culture supernatant were determined by real-time quantitative RT-PCR and ELISA, respectively. Each column represents the mean \pm SD of $n=3$ independent observations in three separate cell culture plates. ${ }^{* *} ; p<0.01$ compared with control. ${ }^{\#} ; p<0.05$ and ${ }^{\# \#} ; p<0.01$ compared with LPS-stimulated vehicle-treated cells.

pathway via inhibition of phosphorylation and degradation of IKB- $\alpha$ and phosphorylation of ERK. The precise mechanism by which LANSO inhibits activation of NF- $\mathrm{KB}$ and ERK remains unknown. LPS and HpWE act as ligands of TLRs, and both NF- $\mathrm{KB}$ and ERK are downstream signaling molecules of the TLRs-signaling pathway [9-11]. Taken together, these findings suggest the possibility that LANSO suppresses phosphorylation and degradation of I $\mathrm{KB}-\alpha$ and phosphorylation of ERK via inhibition of the TLR signaling pathway.

In summary, the present findings highlight the novel antiinflammatory effects of LANSO. LANSO suppressed production of the proinflammatory cytokines TNF- $\alpha$ and IL$1 \beta$ by human monocytic cells stimulated by representative pathogenic bacterial components in the gastrointestinal tract, LPS and HpWE. LANSO is already clinically used for peptic ulcer disease and reflux esophagitis, and it appears possible to extend its clinical application to control of inflammation of the gastrointestinal tract caused by pathogenic bacteria in conditions such as inflammatory bowel disease, chronic active gastritis, and NSAID-induced gastrointestinal injury.

\section{Acknowledgment}

We thank Ms. Chikae Doan for her technical assistance. 


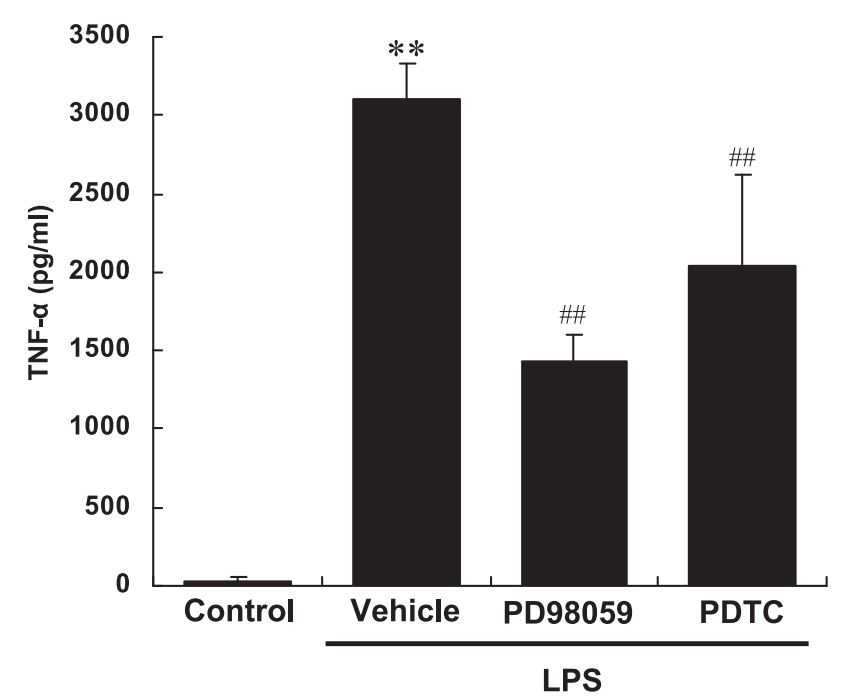

Fig. 3. Effects of PD98059, a MEK inhibitor, and PDTC, an inhibitor of NF- $\kappa \mathrm{B}$ activation, on production of TNF- $\alpha$ by human monocytes (THP-1) stimulated by LPS. After pretreatment with $10 \mu \mathrm{M}$ PD98059 or $100 \mu \mathrm{M}$ PDTC, THP-1 cells were stimulated with LPS $(10 \mathrm{ng} / \mathrm{ml})$ for $3 \mathrm{~h}$. Concentration of TNF- $\alpha$ in cell culture supernatant was measured by ELISA. Each column represents the mean \pm SD of $n=3$ independent observations in three separate cell culture plates. ${ }^{* *} ; p<0.01$ compared with control. \#; $p<0.01$ compared with LPS-stimulated vehicle-treated cells.

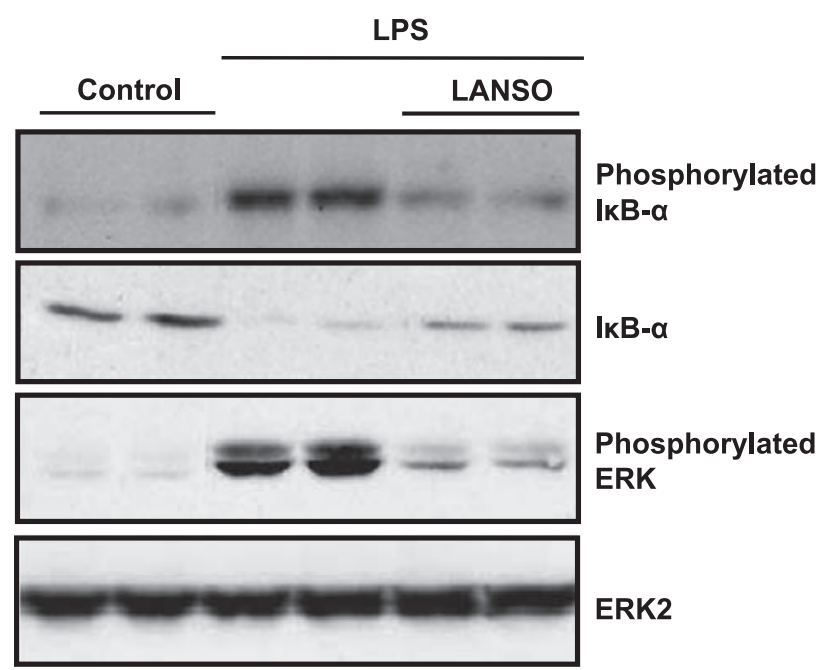

Fig. 4. Effects of LANSO on phosphorylation and degradation of I $\mathrm{B}-\alpha$ and phosphorylation of ERK induced by LPS in human monocytes (THP-1). After pretreatment with $100 \mu \mathrm{M}$ of LANSO, THP-1 cells were stimulated with LPS $(10 \mathrm{ng} / \mathrm{ml})$ for $1 \mathrm{~h}$.

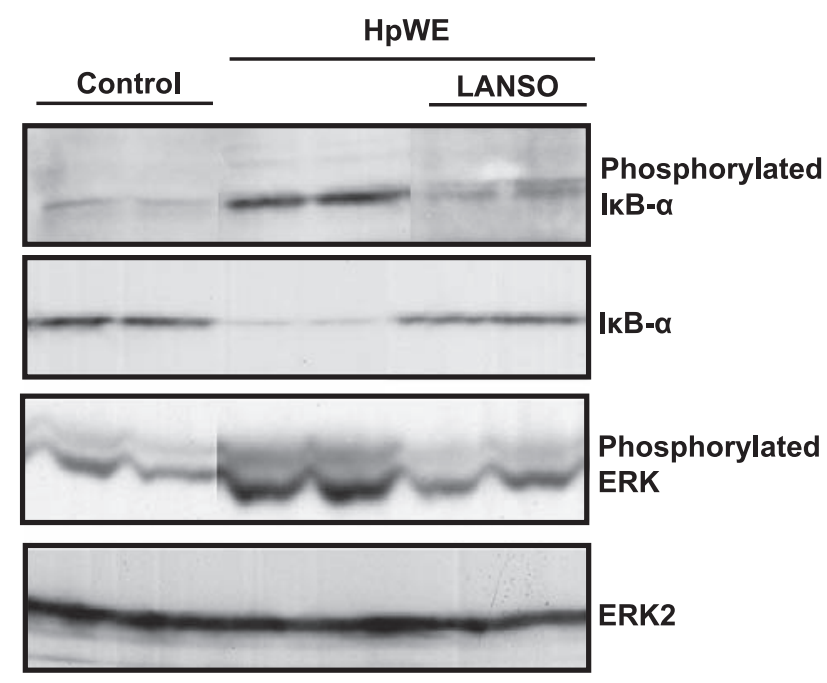

Fig. 5. Effects of LANSO on phosphorylation and degradation of I $\mathrm{I} B-\alpha$ and phosphorylation of ERK induced by HpWE in human monocytes (THP-1). After pretreatment with $100 \mu \mathrm{M}$ of LANSO, THP-1 cells were stimulated with $\operatorname{HpWE}(5 \mu \mathrm{g} / \mathrm{ml})$ for $1 \mathrm{~h}$.

\section{References}

[1] Blaser, M.J., Chyou, P.H., and Nomura, A.: Age at establishment of Helicobacter pylori infection and gastric carcinoma, gastric ulcer, and duodenal ulcer risk. Cancer Res., 55, 562$565,1995$.

[2] Correa, P. and Houghton, J.: Carcinogenesis of Helicobacter pylori. Gastroenterology, 133, 659-672, 2007.

[3] Peek, R.M., Jr. and Crabtree, J.E.: Helicobacter infection and gastric neoplasia. J. Pathol., 208, 233-248, 2006.

[4] Packey, C.D. and Sartor, R.B.: Interplay of commensal and pathogenic bacteria, genetic mutations, and immunoregulatory defects in the pathogenesis of inflammatory bowel diseases. J. Intern. Med., 263, 597-606, 2008.

[5] Watanabe, T., Higuchi, K., Kobata, A., Nishio, H., Tanigawa, T., Shiba, M., Tominaga, K., Fujiwara, Y., Oshitani, N., Asahara, T., Nomoto, K., Takeuchi, K., and Arakawa, T.: Non-steroidal anti-inflammatory drug-induced small intestinal damage is Toll-like receptor 4 dependent. Gut, 57, 181-187, 2008.

[6] Konaka, A., Kato, S., Tanaka, A., Kunikata, T., Korolkiewicz, R., and Takeuchi, K.: Roles of enterobacteria, nitric oxide and neutrophil in pathogenesis of indomethacin-induced small intestinal lesions in rats. Pharmacol. Res., 40, 517524, 1999.

[7] Robert, A. and Asano, T.: Resistance of germfree rats to indomethacin-induced intestinal lesions. Prostaglandins, 14, 333-341, 1977.

[8] Smith, P.D., Ochsenbauer-Jambor, C., and Smythies, L.E.: Intestinal macrophages: unique effector cells of the innate immune system. Immunol. Rev., 206, 149-159, 2005. 
[9] Akira, S. and Takeda, K.: Toll-like receptor signalling. Nat. Rev. Immunol., 4, 499-511, 2004.

[10] Maeda, S., Akanuma, M., Mitsuno, Y., Hirata, Y., Ogura, K., Yoshida, H., Shiratori, Y., and Omata, M.: Distinct mechanism of Helicobacter pylori-mediated NF- $\mathrm{KB}$ activation between gastric cancer cells and monocytic cells. J. Biol. Chem., 276, 44856-44864, 2001.

[11] Smith, M.F. Jr., Mitchell, A., Li, G., Ding, S., Fitzmaurice, A.M., Ryan, K., Crowe, S., and Goldberg, J.B.: Toll-like receptor (TLR) 2 and TLR5, but not TLR4, are required for Helicobacter pylori-induced NF- $\mathrm{BB}$ activation and chemokine expression by epithelial cells. J. Biol. Chem., 278, 32552-32560, 2003.

[12] Becker, J.C., Grosser, N., Waltke, C., Schulz, S., Erdmann, K., Domschke, W., Schroder, H., and Pohle, T.: Beyond gastric acid reduction: proton pump inhibitors induce heme oxygenase-1 in gastric and endothelial cells. Biochem. Biophys. Res. Commun., 345, 1014-1021, 2006.

[13] Handa, O., Yoshida, N., Fujita, N., Tanaka, Y., Ueda, M., Takagi, T., Kokura, S., Naito, Y., Okanoue, T., and Yoshikawa, T.: Molecular mechanisms involved in antiinflammatory effects of proton pump inhibitors. Inflamm. Res., 55, 476-480, 2006.

[14] Ichikawa, H., Yoshida, N., Takagi, T., Tomatsuri, N., Katada, K., Isozaki, Y., Uchiyama, K., Naito, Y., Okanoue, T., and Yoshikawa, T.: Lansoprazole ameliorates intestinal mucosal damage induced by ischemia-reperfusion in rats. World $J$. Gastroenterol., 10, 2814-2817, 2004.

[15] Kuroda, M., Yoshida, N., Ichikawa, H., Takagi, T., Okuda, T., Naito, Y., Okanoue, T., and Yoshikawa, T.: Lansoprazole, a proton pump inhibitor, reduces the severity of indomethacininduced rat enteritis. Int. J. Mol. Med., 17, 89-93, 2006.

[16] Sasaki, T., Yamaya, M., Yasuda, H., Inoue, D., Yamada, M., Kubo, H., Nishimura, H., and Sasaki, H.: The proton pump inhibitor lansoprazole inhibits rhinovirus infection in cultured human tracheal epithelial cells. Eur. J. Pharmacol., 509, 201-210, 2005.

[17] Suzuki, M., Mori, M., Fukumura, D., Suzuki, H., Miura, S., and Ishii, H.: Omeprazole attenuates neutrophil-endothelial cell adhesive interaction induced by extracts of Helicobacter pylori. J. Gastroenterol. Hepatol., 14, 27-31, 1999.

[18] Suzuki, M., Nakamura, M., Mori, M., Miura, S., Tsuchiya,
M., and Ishii, H.: Lansoprazole inhibits oxygen-derived free radical production from neutrophils activated by Helicobacter pylori. J. Clin. Gastroenterol., 20, S93-S96, 1995.

[19] Wandall, J.H.: Effects of omeprazole on neutrophil chemotaxis, super oxide production, degranulation, and translocation of cytochrome b-245. Gut, 33, 617-621, 1992.

[20] Yoshida, N., Yoshikawa, T., Tanaka, Y., Fujita, N., Kassai, K., Naito, Y., and Kondo, M.: A new mechanism for antiinflammatory actions of proton pump inhibitors - inhibitory effects on neutrophil-endothelial cell interactions. Aliment. Pharmacol. Ther., 14, S74-S81, 2000.

[21] Suzuki, M., Suzuki, H., and Hibi, T.: Proton pump inhibitors and gastritis. J. Clin. Biochem. Nutr., 42, 71-75, 2008.

[22] Naito, Y.: Anti-inflammatory and anti-oxidative properties of proton pump inhibitors. J. Clin. Biochem. Nutr., 41, 82-83, 2007.

[23] Nakamura, M., Matsui, H., Serizawa, H., and Tsuchimoto, K.: Lansoprazole Novel Effector Sites Revealed by Autoradiography: Relation to Helicobacter pylori, Colon, Esophagus and Others. J. Clin. Biochem. Nutr., 41, 154-159, 2007.

[24] Sanceau, J., Kaisho, T., Hirano, T., and Wietzerbin, J.: Triggering of the human interleukin- 6 gene by interferon- $\gamma$ and tumor necrosis factor- $\alpha$ in monocytic cells involves cooperation between interferon regulatory factor-1, NFKB, and Sp1 transcription factors. J. Biol. Chem., 270, 2792027931, 1995.

[25] Durando, M.M., Meier, K.E., and Cook, J.A.: Endotoxin activation of mitogen-activated protein kinase in THP-1 cells; diminished activation following endotoxin desensitization. J. Leukoc. Biol., 64, 259-264, 1998.

[26] Zhang, F.X., Kirschning, C.J., Mancinelli, R., Xu, X.P., Jin, Y., Faure, E., Mantovani, A., Rothe, M., Muzio, M., and Arditi, M.: Bacterial lipopolysaccharide activates nuclear factor- $\mathrm{KB}$ through interleukin-1 signaling mediators in cultured human dermal endothelial cells and mononuclear phagocytes. J. Biol. Chem., 274, 7611-7614, 1999.

[27] Bhattacharyya, A., Pathak, S., Datta, S., Chattopadhyay, S., Basu, J., and Kundu, M.: Mitogen-activated protein kinases and nuclear factor- $\mathrm{\kappa B}$ regulate Helicobacter pylori-mediated interleukin-8 release from macrophages. Biochem. J., 368, $121-129,2002$. 